\title{
CREATING A BRITISH WORLD: BRITISH COLONIAL TEACHERS AND THE ANGLICISING OF AFRIKANER CHILDREN
}

\author{
DOI: http://dx.doi.org/10.17159/2223-0386/2016/n15a1 \\ Cheryl S le Roux \\ College of Education \\ Department of Educational Foundations, UNISA \\ Lrouxcs@unisa.ac.za
}

\section{Abstract}

The contribution of the British Colonies in supporting Britain in its quest to promote English and British culture amongst Afrikaner children during and in the aftermath of the Anglo Boer War is examined in this article. A cursory background to the circumstances that shortly preceded the Anglo Boer War is provided to present the context of the study. Next, the role of the press in shaping opinions on and attitudes towards the key role players in the war is offered. This aspect is included since it points to how the opinions of British colony teachers who were recruited to teach Afrikaner children in South Africa had been shaped. This section is followed by an overview of concentration camp schools and an outline of the prevailing conditions of schooling at that time. Hereafter the experiences of teachers who had been recruited from each of three British Colonies - New Zealand, Canada and Australia - are presented. These experiences give the reader insight into how teaching occurred, what it comprised and how it was received by Afrikaner children who survived the concentration camps. This article aims to add to the body of knowledge on schooling during the time of the Anglo Boer War and the role that the British played in the provisioning of education. The article also outlines the attempts of the British to Anglicise Afrikaner youth. The research evidences that the explicit role of these teachers was to inculcate the English language and customs in Afrikaner children during and after the Anglo Boer War.

Keywords: Anglo Boer War; Anglicisation; British imperialism; Colonial teachers; Concentration camps; South African colonial schools; Colonial Australian teachers; Colonial New Zealand teachers; Colonial Canadian teachers. 


\section{Introduction}

If one were to reflect on the social and political history of South Africa from its earliest days, two issues come to mind. Firstly, the inhabitants hailed from various parts of the world and depending on the prevailing circumstances, sought - to varying degrees - either social integration or segregation. Secondly, for roughly two and a half centuries (1652-1948) the country was subjected to European influence and rule either under the Dutch or the British with each sovereignty seeking to impress its particular social and political character on the nation - often through education.

The first of the social assimilation policies - that of Governor Simon van der Stel (1679-1691) - was effected soon after the French Huguenots arrived in the Cape in 1685. Although the first school that was established for Huguenot children (1688) employed a teacher who understood both French and Dutch and much of the teaching was in French, within two years, it had been decided that French children should be instructed in Dutch (Theal, 1882:291). Subsequently Dutch custom and language became entrenched (Le Roux, 1998:108). The second wave of assimilation can be attributed to the efforts of Sir John Cradock (1811-1814) who initiated an Anglicisation policy which was subsequently propagated in earnest by Lord Charles Somerset (18141826) in 1822 when he proclaimed that English would become the official language of the Colony (Eybers, 1918:23). In 1879 at the time of the De Villiers Commission of Enquiry into Schooling, the Judge of the Supreme Court advocated that the English should be required to learn Dutch to ensure a more equitable situation (De Villiers Commission, 1879:476). Clearly the issue of language and culture was contentious and vacillating.

In this article, the contribution of the British Colonies in supporting Britain in its quest to promote English and British culture amongst Afrikaner children during and in the aftermath of the Anglo Boer or South African War as it is currently referred to, is examined. A cursory background to the circumstances that shortly preceded the Anglo Boer War is provided to present the context of the study. Next, the role of the press in shaping opinions on and attitudes towards the key role players in the war is offered. The justification for the inclusion of this section is that it provides the reader with an idea of how the opinions on the circumstances in South Africa of British Colonial teachers who were recruited to teach South African children had been formed. This section is followed by an overview of concentration camp schools and an outline of the prevailing conditions of schooling at that time. Hereafter the experiences 
of teachers who had been recruited from each of the British colonies - New Zealand, Canada and Australia - is presented. These experiences give the reader an insight into how teaching occurred, what it comprised and how it was received by these children who had survived the traumatic conditions of the concentration camps. This article thus aims to add to the body of knowledge on schooling during the time of the Anglo Boer War and the role that the British played in the provisioning of education and the attempt at the Anglicisation of Afrikaner youth. The research will evidence that the explicit role of these teachers was to inculcate the English language and customs in the Boer children.

\section{Underpinning suppositions}

A review of recent research and discourses in relation to the Anglo Boer War indicates that there is substantial interest in the subject from a variety of perspectives. Postmodern and idiographic studies of the history of this time have been undertaken, as well as a substantial number of studies that have pursued the topic from a gender and from a racial issue stance (cf. Denness, 2012b; Riedi, 2002 \& 2005; Van Heyningen 1999; Vergolina, 2012). This particular study looks at the contribution of three specific women teachers (who were recruited from the British colonies) to educate Afrikaner children during the Anglo Boer War and thereafter. The study does not adopt a gender stance on the topic, but rather an idiographic historical perspective in that the approach to investigating the topic has been focused on attempting to achieve a unique understanding of the individual in a personal and in-depth manner (Tsoukas, 1989:551).

The issue of the Anglo Boer War itself can be viewed from different viewpoints from a pro-Boer (anti-war activist) to a jingoist (imperialist) perspective. However, this article attempts to present the topic from a neutral position. McCullagh (2000:42) points out though that when historians describe something - a person, an event, a condition - only certain aspects are presented. The aspects that are chosen for examination and description are those that appeal to and are of interest to the researcher. For this reason, it is clear that such presentations will undoubtedly be fair game for criticism and perhaps even denigration by those who would have adopted a different stance towards the research. However, the freedom to criticise the views of others is a precondition for arriving at a fair description of the past and perhaps it is expedient to understand history as a cooperative enterprise with 
historians working together to arrive at adequate accounts of the past (Haskell, 2000:134). The author has attempted to provide a factually correct and balanced perspective on the issues discussed in this article, but acknowledges that other researchers could approach the topic from a different position.

\section{Background and the contextualisation of the study}

At its peak, the British Empire that comprised dominions, colonies, protectorates, mandates and other territories ruled or administered by the United Kingdom, was the most extensive formal empire and foremost global power in world history (Ferguson, 2004:ix; Jackson, 2008). One of the colonies formally acquired by Britain in 1806 (after having occupied it in 1795 at the bequest of the Netherlands to prevent it from falling into French hands) was the Cape Colony with the Boer or Afrikaner population being in the majority of the European population. The British population in the Colony grew as a consequence of immigration efforts in the 1820s and this, among several other reasons including Britain's emancipation of the slaves (1833), thrust thousands of Boers, resentful of British rule, northwards (cf the Great Trek, 1836) to establish their own independent republics namely the Zuid-Afrikaansche Republiek (ZAR) (also known as the South African or Transvaal Republic)(1852-1877; 1881-1902) and the Orange Free State (1854-1902). Both republics were occupied by Britain subsequent to the Anglo-Boer war (1899-1902) (Pretorius, 2014).

The impetus for the Anglo Boer War was the discovery of diamonds in the Orange Free State (1870s) and gold (1886) on the Witwatersrand in the ZAR, which gave rise to an influx of foreigners (especially to the ZAR) to work the mines. Furthermore, the discovery of such wealth fueled British imperial ambitions. The mine owners were English speakers with little or no loyalty to the Afrikaner Republics and by the late 1890s the Uitlanders (as the immigrants were called by the Afrikaners) constituted a major part of the white male population. President Kruger of the ZAR was reluctant to expand the franchise to the Uitlanders for fear of them gaining political power. After Cecil Rhodes' abortive Jameson raid (1895) Kruger had further reason to distrust the mine owners and immigrants and he continued to deny the vote to Uitlanders. A sense of Afrikaner identity and individualism increasingly took shape. This identity started to spread across regional boundaries and soon included Dutch speakers in the Cape and the citizens of the Orange Free State. The British government (in the persons of Joseph Chamberlain, Secretary 
of State for the Colonies, and Alfred Milner, High Commissioner in South Africa), continued to denounce Kruger and his government. Chamberlain was firm in his belief that the British needed to take direct action to contain Afrikaner power. At first, diplomatic channels were used to try to pressure Kruger into granting the vote to the Uitlanders, but these were unsuccessful. Milner's stance was that as long as these Uitlander British subjects in the ZAR found themselves without the vote, they were "kept permanently in the position of helots constantly chafing under undoubted grievances and calling vainly to Her Majesty's Government for redress". He was of the opinion that this situation "steadily undermine[d] the influence and reputation of Great Britain and the respect for the British Government within its own dominions" (Thompson, 2007:131). In 1899 Milner advised Chamberlain that he considered the case for British intervention "overwhelming". Ignoring attempts by Kruger to reach a compromise, in September 1899, Chamberlain issued an ultimatum requiring that Kruger enfranchise British residents of the ZAR. At the same time, Chamberlain sent troop reinforcements from Britain to the Cape. Kruger, certain that Britain was bent on war, took the initiative and, allied with the Orange Free State, declared war on the British in October 1899 (Pakenham, 1979:52-53; Pretorius, 2014; Scholtz, 2000:11-17).

The Anglo Boer War (1899-1902), fought by Britain and her Empire to establish her domination in South Africa and by the Afrikaners and their sympathizers to defend their autonomy, lasted three years and caused enormous suffering. At the beginning of the war, the Afrikaner forces had the superiority and won many battles. With reinforcements added to the British army, however, the Afrikaners soon found themselves in dire circumstances. Resistance continued after various British victories with the Afrikaners resorting to fighting a ferocious and intermittently successful guerrilla war. The British ultimately succeeded in breaking this resistance, but only after adopting a scorched-earth policy. In 1901 and 1902, the British torched more than 30,000 farms in the South African Republic and the Orange Free State and relocated Afrikaner women and children from these farms and surrounding villages to concentration camps that were somewhat hastily established to house these refugees. The concentration camps were notorious and because of overcrowding, unsanitary conditions, malnutrition and disease 27927 Afrikaner women, children and men perished in these camps. Peace was finally concluded in May 1902 with the Afrikaners handing over their arms and conceding the incorporation of their territories into the British Empire as the Orange River Colony and the Transvaal (Pretorius 1998:35, 
48, 66; Scholtz, 2000:114).

It was during the period of the establishment of the concentration camps and in the aftermath of the war that Britain made a concerted effort to bring British culture, values and the imperial language to Afrikaner children to prepare them to become citizens of the British Empire. Lord Roberts made it clear that concentration camp inmates were regarded as British subjects and, as such, they were expected to become part of a self-governing dominion of the Empire (Smith \& Stucki, 2011:427).

\section{The press as opinion former}

The print media is to this day indisputably an effective instrument in the manufacturing of its readership's opinions on matters both local and international. The situation in the years and months leading up to the conflict in South Africa was no different and the attitudes and beliefs of the South African, British and Colonial public were shaped by the prevailing political discourses as well as what they read in print (Karageorgos, 2014:120). Most provincial newspapers in Britain received their information from London newspapers which obtained their information from correspondents who staffed newspapers in Cape Town and Johannesburg (Kent, 2013:3). The press in the British colonies, however, closely followed Britain's journalism (Karageorgos, 2014: 122) ${ }^{1}$. The Johannesburg-based newspapers were fervently jingoistic, while the provincial or small-town English language newspapers were proBoer (ie anti-war activists) (Dugmore, 1999:248). Dugmore (1999:255-257) contends that the small town newspaper editors had a degree of independence - unlike the Johannesburg newspapers which were owned by those "who own[ed] or control[ed] the diamond mines in Kimberley" (Kent, 2013:3) - and initially took a strongly independent and essentially pro-Boer stand before the outbreak of the war. Another justification for this difference in stance is to be found in the existing social circumstances. In Johannesburg the sprawling working class suburbs ensured that English-speaking workers had little contact with the Boers and it was easy to construct patterns of identity that stressed "Englishness" in a way that "othered" the Boers, while in the smaller towns, British and Boers intermingled and the Uitlander Briton was respectful of the sober, God-fearing Boer. The pro-war newspapers claimed that the British would be fighting against tyranny - the British Uitlanders

1 Colonialists such as the people of Australia, Canada and New Zealand largely viewed themselves as British subjects and part of the mighty British Empire. 
were being taxed but denied the vote by the Boer leader, Paul Kruger. The proBoer newspapers argued that imperialist criticism of the Kruger government and attempts to whip up a case for war were contrary to British "fair play" and amounted to a tyrannical imposition of the will of a mighty power on a smaller, independent power (Dugmore, 1999:246).

As such, a certain perception and understanding of both the Boer and the Uitlander were inculcated in the British and Colonial public. Even before the British and imperial soldiers arrived in South Africa, they already had established assumptions of the nature of the citizens of the country. The Uitlanders were portrayed as a group without social and political rights thereby emphasising the anti-democratic tendencies of the Boer who was unwilling to share the virtues and rewards of citizenship with them (Miller, 2013:1334). The Daily Telegraph (1899) called for the immediate liberation of these disenfranchised immigrants who had "suffered for years grave indignities and disabilities at the hands of a stupid and domineering oligarchy of Boers" and were appealing to Britain for assistance. Miller (2013:1335) contends that these cries against oligarchy and the disenfranchisement of British subjects resonated with the British and "pushed men into recruiting offices".

Nevertheless, public opinion was divided between those who supported and those who opposed the Anglo Boer War. Most anti-war activists did not dispute the importance of the sovereignty of the British Empire but argued that Britain had subverted the imperial mission by fighting against another white, Protestant, and politically independent African nation. Their portrayal of the Afrikaner emphasised similarities with Britishness (Mader, 2012).

On the other hand, those who supported the war focused on the Boers' lack of refinement and their lack of likeness with Britons (Mader, 2012). The perception that Afrikaners were in need of civilization can be attributed to comments such as those made by Kitchener who described the Boers as "uncivilized Afrikander savages with only a thin white veneer" (Kitchener, 1901). It would seem that these kinds of British observations on South African society were that Afrikaners did not conform to the essential elements of civilized British society. For example, James Bryce (1896) in The Times argued that the Boer's isolated lifestyle ensured the "children grew up ignorant; the women ... lost the neat and clean ways of their Dutch ancestors; the men were rude, bigoted, indifferent to the comforts and graces of life". Denness (2012a: 56) argues that this was typical of pro-war British thought and that images of the Boers were constructed on their failure to conform to British norms of 
domesticity and refined femininity, and industrious, chivalrous masculinity. The image of a backward and uncivilized Boer nation was perpetuated and expanded in the British press (Denness, 2012a:70). Karageorgos (2014:123) points out that since the Boers were also white Europeans, the "otherness" had to be established based on their behavior rather than skin colour. British observers consequently used these perceptions created in the press as yardsticks to measure levels of civilization. A sense of a misshapen culture that lacked proper order and mores was created which in turn pointed to a desperate need for civilization.

That the concentration camps offered a wonderful opportunity to reach the Afrikaner youth cannot be disputed since by the beginning of 1902, more Afrikaner children were attending the camp schools established by the British than had ever been the case in the pre-war republics (Zietsman, 2001:89). Since there was a dire need for teachers in these camps due to the high number of children in attendance, teachers were recruited in Britain and its colonies and dispatched to the camps to take up the cause of education (Smith \& Stucki, 2011:428).

\section{Establishment of the concentration camp schools}

Edmund Beale Sargant, education secretary, was the driving force behind the establishment of the concentration camp schools. Through his travels across the dominions investigating the influence of educational systems on imperial unity, he was able to form opinions on the matter and the concentration camp schools gave him the opportunity to put these views into practice (Riedi, 2005:1320). His first opportunity arose when he established the first concentration camp school in late January 1901 in Norval's Pont. The success of this school motivated him to extend the process over the whole British concentration camp system in South Africa. Milner (1902) credited him as a "genius as an educationalist and worth his weight in gold". Emily Hobhouse approved of the schools which she described as "the only bright spot in the camp life" as did Fawcett's Ladies' Committee ${ }^{2}$ who thought them "amongst the most cheerful features of the camps" (cited in Riedi, 2005:1230).

There can be little doubt that these camp schools had political overtones

2 The Fawcett Ladies' Committee, under the guidance of Millicent Fawcett, was sent over from Britain during the Anglo Boer War to inspect the conditions in the concentration camps and to advise the British government of the conditions and possible recourse. Emily Hobhouse played an important role in establishing the group but was not part of the committee that came to South Africa. 
and that the schools represented the ideal opportunity to institute Milner's Anglicisation project. Education was perceived as having the ability to fundamentally change the national character of the Afrikaner thereby creating a harmonious and Anglicised South Africa. In Sargant's words, he wanted to win over "the young generation of Dutch Africanders to English ways of thought and speech and to English ideas of truthfulness and loyalty" (Sargant, 1901b). This would go a long way in bringing modern civilization and progress to the nation. Central to this notion was the inculcation of English and a total immersion programme which Sargant justified by commenting that "the fact that some children know scarcely a word of English is not a reason for speaking to them in Dutch" (Sargant, 1901b). Riedi (2005) cites the British politician, Alfred Lyttleton, as being of the opinion that schools for the Afrikaner children "will go far ... in the future to cement the relations between the Dutch and English populations".

School enrollment increased exponentially reaching a peak in May 1902 when there were over 17000 children in the Transvaal camp schools and over 12000 in the Orange River Colony (Riedi, 2005:1321). ${ }^{3}$ These numbers were considerably higher than the Boer republics had achieved in peace time. A significant problem faced by the schools was adequate teaching staff. There was a limited supply of Afrikaner women from within or near the camps to staff the schools, and it became necessary to employ camp inmates with limited education whom Fawcett (1902) of the Ladies' Committee described as being "nearly impossible to understand when they think they are speaking English". She consequently urged the British government to urgently recruit trained English teachers to be deployed to the concentration camp schools. This sentiment was echoed by Sargant (1901a) who told Milner that he needed to appeal to Britain for "thoroughly good teachers ... of patriotic mind". He further believed this was a golden opportunity to get the Afrikaner children to speak English. Milner subsequently appealed to the Colonial Office that it was imperative to acquire extra teaching staff and recommended that identified school boards be approached to provide "lady volunteers" with four or five years of experience in infant work. He further outlined their salary and relocation arrangements but emphasised that the task would be to "bring them [the Afrikaner children] under influences that will promote future harmony of races". He assured these prospective teachers that their reception would be courteous and that the children were willing to learn and were amenable to discipline.

3 At this time a small number of town schools in the two republics remained functional with some 13000 children in attendance. 


\section{Foreign teachers}

The success of the schools established in the concentration camps can be deduced from the number of attendees - especially when one considers that attendance was voluntary. Given this situation, the need for teachers for these schools was critical. In November 1901 the British government therefore advertised for experienced female teachers across the United Kingdom to volunteer their services in the concentration camp schools in South Africa. Between January and March 1902 a similar advertisement was placed in newspapers in the British colonies of Australia, New Zealand and Canada. An initial quota of 100 teachers was set for the United Kingdom (this was later increased by another one hundred teachers) while Australia and Canada were each awarded a quota of 40 teachers and New Zealand was requested to provide 20. The response was significant. In Canada over 1000 women applied, in Australia there were over 350 applicants, and in New Zealand, the selection of 20 was made from 222 applications (Riedi, 2005:1327).

Unique to the situation of recruiting teachers for the concentration camp schools was the fact that the British government, while engaged in hostilities with the Boers, resolved to send teachers to educate and care for the children of the enemy (Ellis, 2003: 140; Schoeman, 2013:177). Furthermore, the fact that ultimately one third of the teachers was recruited from the self-governing dominions, gives one insight into the relationship between imperial loyalty and colonial nationalism at that time (Riedi, 2005:1319).

On 6 November 1901, an advertisement was placed in The Times (1901) in the United Kingdom on behalf of the Board of Education requesting trained women teachers with four to five years of experience in teaching little children to volunteer to work in the refugee camps in South Africa for the term of one year. At the end of the contract, volunteers had the option of returning home, or if they so wished and were found suitable, to be permanently employed in the country. The salary offered was $£ 100$ per annum as well as free accommodation and rations. Selected volunteers would be given a second class passage to their destination. In addition to being proficient in teaching younger children, prospective teachers were required to have the ability to teach singing, be of good physique and be able to endure stringent living conditions. Between January and March 1902, the call for teachers was extended to the British Colonies of Australia, New Zealand and Canada with equally strict selection criteria (Ellis, 2003: 141; Schoeman, 2013:178). 
Canada was the first to respond to the call for teachers. On 12 April 1902, the first contingent of 20 Canadian teachers set sail for South Africa; the second group following a week later. The groups arrived in Cape Town at the beginning of June shortly after peace had been declared (Schoeman, 2013: 162). The teachers were deployed to camps in the Cape Colony and the Orange River Colony. The 20 New Zealand teachers who departed New Zealand on 4 May 1902, arrived in Durban on 5 June 1902 and the majority were sent to teach in concentration camp schools in Natal although two teachers were deployed to the Volksrust camp just across the Natal border in the Transvaal (Phillips, 2012). By the middle of July 1902, the Australian teachers had been selected and set sail for South Africa in August, arriving in Cape Town on the 25th of August 1902 (McInnes, 1902a). These teachers were deployed to camps in the Orange River Colony, the Transvaal and the Cape Colony (McInnes, 1902b).

\section{Recruitment and possible motivation for applying}

Although by the time the teachers arrived the war was ending, they were deployed to the camps which would take some time to close. As the concentration camp schools disbanded, the teachers were deployed to teach in town and farm schools. However, this took time and in certain instances, recruited teachers would wait several months before being deployed and taking up active teaching duties (McInnes, 1902d).

Suggested motives for applying to teach in South Africa include imperial loyalty and a desire to be part of the war-effort; financial need (the salary of $£ 100$ per annum was generally higher than that paid in the colonies - one teacher, Margaret McInnes (1903b) comments in a letter home after accepting an extension to her one- year contract, "How the Education Department are slaughtering the salaries at home [Australia]. I'd have not got my rise this year if I'd been there"); ties with South Africa (some had relatives who had been recruited into the army); career advancement; and a sense of adventure (Riedi, 2005:1331).

\section{Profile of the prospective teachers}

The New Zealanders were the first generation of girls to be educated under a free public school system enshrined in the New Zealand Education Act of 1877 and were among the first women professionally trained at the new 
teachers' training colleges. Most of the successful applicants were born and raised in rural areas or in small towns. All the women were unmarried and were aged between 28 and 38 years of age (Ellis, 2003:141).

In the case of the Canadian recruits, Riedi (2005:1327) notes that Lady Cecil's comment that they were "very nice-looking, nice mannered and not a bit gauche" suggests that they had solid middle-class backgrounds. One quarter of the Canadian teachers had a university education.

That these young women were endowed with a sense of adventure is attested to in the comments made in their letters home. Agnes Don from New Zealand related that " ... in reality we would not have missed the thrilling times for anything, and if our future camp life at all resembles the three days we have spent here, it will be far removed from commonplace" (Otago Daily Times, 1902).

Generally the women were enthralled by the country. Upon her arrival in Durban, Hilda Ladley wrote home "... we have fallen in love with Durban" (Schoeman, 2013: 181). Margaret McInnes, one of the Australian teachers, wrote "Cape Town's lovely, grand, magnificent. Words simply fail. I never thought such beauty could be" (McInnes, 1902a).She also commented in a later letter home (McInnes, 1902c) that "We are enjoying ourselves, occasionally we pinch each other to make sure it's not all a beautiful dream." Nan Parker, a New Zealander who was deployed to the Volksrust camp, wrote home " ... you have no idea of the grandeur of a sunset when you are alone in the veldt ..." and, at the end of her sojourn in South Africa upon her immanent return home " ... now that my time is drawing near, I shall be awfully sorry to say goodbye ...” (Parker cited in Ellis, 2003:147).

\section{Schooling in the concentration camps}

The Colonial teachers were deployed to the concentration camps where they generally taught alongside established Dutch and British teachers. Hilda Lindley and seven other New Zealand teachers at Merebank were supported by 12 English teachers, 28 Dutch teachers and a headmaster. Maud Graham was one of four Canadian teachers deployed to the camp in Norval's Pont and she mentions that there was already a group of six English teachers at the camp. She also mentions a Dutch assistant who assisted her in taking the roll call as she struggled to pronounce the Dutch names (Schoeman, 2013:165). 
As already mentioned, school attendance was voluntary. The school day in the camp schools usually began at 8.30 am (although some started at 9.00 am and ended a half hour later) with half an hour of religious instruction that included Bible reading and singing taken by a Dutch teacher. This was followed by two sessions - the one until 11.00 am followed by recess of half an hour and the second session until $1.00 \mathrm{pm}$. (Ellis, 2003:145). Class sizes and the age range of the children in the class varied considerably. It was not uncommon to find that the infant class comprised children between the ages of 5 and 15 since these schools offered several older children their first opportunity to attend school. Initially the classes were very large, but as the concentration camps were disbanded, the numbers dwindled and class sizes were considerably reduced. Maud Graham reported that the class of 300 children was divided upon her arrival to Norval's Pont with her taking 130 children and the English teacher the remaining 170. In a letter dated 5 September 1902, Margaret McInnes (1902c), an Australian teacher deployed to Irene camp, commented that in June of that year there had been "1100 children in the school - now they number 16". Classes in town and farm schools were generally small (McInnes, 1902f).

The teachers taught basic subjects such as reading, writing and arithmetic, as well as singing and physical education. Writing comprised mostly of copying figures or letters from examples written on the blackboard. Reading comprised reading off a big reading sheet. Singing was found to be an excellent and quick way of teaching English and was popular with the teachers. Mental arithmetic, spelling, memorisation of verse, listening to stories and illustrated talks were a part of each school day. The only history permitted in the classes was British colonisation and exploration. Teachers were also responsible for inspecting the children's hygiene and cleanliness. Recess was generally spent with the boys playing marbles and the girls skipping rope (Schoeman, 2013:167; 185).

The teachers generally described their duties as light and the teaching elementary. Clearly duties at home were more taxing than in South Africa as McInnes (1902f) comments "It's a dreadfully lazy life here. I can't get used to teaching 20 children especially as they only learn reading, writing $\&$ arithmetic and that lot all over at one o'clock." A few months later she (McInnes, 1903c) comments that "I've got a new class at school now. Got tired of my few and asked for more work. I've fifty now all ages from five to fifteen. Most of them don't know a word of English. It's funny as can be to hear my Dutch and their English". Because they did not know the language, 
the Colonial teachers generally had difficulty in pronouncing the names of the children in their classes, and when required to do roll call many mention that one of the Dutch teachers would call roll on their behalf (Ellis, 2003:145; McInnes, 1902c; Schoeman, 2013:165-167).

The teachers were pleasantly surprised at the children's abilities and demeanor which was in stark contrast to the derogatory anti-Boer propaganda to which they had been exposed. Lindley commented that "The children are very nice to teach and most intelligent ..." Maud Graham, a Canadian teacher comments on their visit to a small school in the Cape Colony which they visited en route to the Norval's Pont camp that they were corrected of their preconceived ideas of schools in South Africa by its up to date organisation and teaching methods (Schoeman, 2013:163). Comments about the children's good behavior ("pretty manners"), attentiveness, friendliness and keenness to learn are common amongst all groups of colonial teachers. Graham comments that “... Boer children were never so quarrelsome and boisterous as American children, but they were just as fond of fun as any children I ever met" (Schoeman 2013:168). Regarding their good manners, McInnes (1902g) comments "They're so full of manners ... it's 'Yes Missus \& No Missus' all the time".

\section{Redeployment after the closure of the concentration camp schools}

Apart from the town schools that had continued to run during the war, several other schools were established in towns held by the British with the military authorities often taking the initiative in this regard. Six months after the cessation of hostilities there were 79 town schools in operation (Transvaal Education Department, 1902:3). Furthermore, once the Boers returned to their farms, many country and farm schools were established. In September 1902, ten farm schools were opened and by the end of January 1903, they numbered 101 (Transvaal Education Department, 1902:2; Transvaal and Orange River Colony, 1904:12-16).This meant that as the concentration camps slowly disbanded and the number of children dwindled, the teachers were needed for redeployment in the town and farm schools.

Irene camp was a recruiting and relieving depot where teachers came to await orders and get their teaching equipment before being posted to farm or town schools (McInnes, 1902d; Schoeman, 2013:188). It would appear that deployment to farm schools was a contentious issue and McInnes (1902h) 
was particularly concerned about being posted to a farm school. This seems to have been a general feeling amongst some of the teachers. McInnes comments "We are still threatened with a farm school. There are several near here and not a teacher will volunteer. The authorities say now they'll have to compel the teachers to go or else ask them to resign. They have promised, though, that a teacher will not be asked to go alone. They'll send two together so that it won't be so very bad perhaps". In her next letter home (McInnes, 1902i), the matter is still foremost in her mind, "They are still worrying us to go to farm schools but I don't move from this place as long as I can dodge it". A while later, it would seem her worst fears had been realised and she writes (McInnes, 1903a): "This is probably the last letter you'll get from me here. I'm being transplanted to a farm school away in the wild of the Transvaal beyond Ventersdorp. ... They all tell us we'll have an awfully good time. The settlers are so anxious to have their children taught that they just bow down to the teachers. And promise anything if we'll only come". To make teaching in farm schools more attractive - it was an almost insurmountable task to obtain the necessary equipment and furniture from Cape Town for these schools apart from their salary of $£ 100$ per annum, teachers were given $£ 75$ a year for rations and a bonus of $20 \%$. Teachers to the farm schools were deployed to pairs and often returned to the camp for their weekends. Furthermore, they were taken to the nearest town once a month for entertainment and diversion (Schoeman, 2013: 189).

A large number of the colonial teachers extended their year contracts and continued teaching in town and farm schools after the concentration camps were closed. Some stayed on in South Africa, several were married and continued their teaching careers while others, after having completed their extended contracts, returned to their home countries. Ellis (2010) reports that only six of the 20 teachers returned to New Zealand and those that did found that their lives had been forever changed by their experiences in South Africa.

\section{Conclusion}

British subjects appeared to have viewed the world through imperialist eyes and their perspectives on education were intertwined with their views of the motherland and her subjects and what constituted civilization. It would seem that in their expansionist quest, the British developed a sense of their own destiny and moral responsibility in respect of the rest of the world. Britain 
appears to have believed that many of her colonial subjects required guidance and that it was British rule that prevented anarchy and chaos (Phillips, 2014:71). It is probably owing to this assumed sense of responsibility and the perception that the establishment of British rule supported civilization that the desire and imperative to Anglicise the Afrikaner nation that occupied the southern tip of Africa is to be found.

The British and colonial women who were recruited to teach in the concentration camp schools were part of an imperial project to introduce Boer children to the British language and culture. Simultaneously, recruitment of teachers from the white British colonies could be described and an attempt to draw the Empire closer.

Impressing the British culture on the Afrikaner was also intended as "ending the retrogression of the Boers" and making them outward-looking and open to progress and modern civilization (Riedi, 2005:1320). Boer children were to be raised according to a characteristically British model of middle-class childhood. This model emphasised education and constructive play (Duff, 2014:368). The role of the colonial teachers in educating Boer children is insightfully articulated by Lindley who comments in a letter to the Colonist (1902) that "... we are really expected not so much to educate them as to make them English, and fond of the English ways." The efforts described in this article noticeably point to concerted attempts by the British to transform Afrikaner children into true, British subjects thereby creating an emerging British world on the southern tip of Africa.

\section{References}

Bryce, J 1896. The Transvaal Boer III, The Times, 1 January.

Cape of Good Hope 1879. Report of a commission appointed in accordance with a resolution of the House of Assembly, to enquire into and report upon the working of the education acts in force in this colony. (De Villiers Commission). Cape Town: Solomon.

Colonist, XLV Issue 1902. 10468, 23 July.

Daily Telegraph, 1899. 19 September.

Denness, ZA 2012a. A question which affects our prestige as a nation: The history of British civilian internment, 1899-1945. Unpublished PhD thesis. Birmingham: University of Birmingham. 
Denness, ZA 2012b. Women and warfare at the start of the twentieth century: The racialization of the 'enemy' during the South African War (1899-1902). Patterns of Prejudice, 46(3-4):255-276.

De Villiers Commission. See: Cape of Good Hope.1879. Report of a commission appointed in accordance with a resolution of the House of Assembly, to enquire into and report upon the working of the education acts in force in this Colony. Cape Town: Solomon.

Duff, SE 2014. "Capture the children": Writing children into the South African War, 18991902. The Journal of the History of Childhood and Youth, 7(3):355-376.

Dugmore, C 1999. From pro-Boer to jingo: An anaylsis of small town English language newspapers on the Rand before the outbreak of war in 1899. South African Historical Journal, 41:246-266.

Ellis, E 2003. New Zealand women and the war. In: J Crawford \& I McGibbon (eds.). One flag, one queen, one tongue. Auckland: Auckland University Press.

Ellis, E 2010. Teachers for South Africa. New Zealand Women at the South African War Concentration Camps. Paekakariki: Hanorah Books.

Eybers, GW 1918. Selected constitutional documents illustrating South African History, 17951910. London: Routledge.

Fawcett, M 1902. Report on the concentration camps in South Africa by the Committee of Ladies appointed by the Secretary of State for War. Cd 893.

Ferguson, N 2004. Empire, The rise and demise of the British world order and the lessons for global power. New York: Basic Books.

Haskell, TL 2000. Objectivity is not neutrality: Explanatory schemes in History. Baltimore: John Hopkins University Press.

Jackson, A 2008. The British Empire and the First World War. BBC History Magazine 9(11). Available at https://britishempireatwardotorg.files.wordpress.com/2012/09/ bbc-history-magazine2.pdf. Accessed on 10 November 2015.

Karageorgos, E 2014. Educated, tolerant and kindly: Australian attitudes towards British and Boers in South Africa, 1899-1902. Historia, 59(2):120-135.

Kent, KS 2013. Propaganda, public opinion, and the Second South African Boer War. Available at http://www.studentpulse.com/articles/781/2/propaganda-publicopinion-and-the-second-south-african-boer-war. Accessed on 19 May 2015. 
Kitchener, H 1901. Kitchener to Brodrick (War Office) 21 June 1901. Kitchener Papers 30/57/20/2 National Archives: Kew.

Le Roux, CS 1998. A historical-educational appraisal of parental responsibilities and rights in formal education in South Africa (1652-1910). Unpublished D Ed Thesis. Pretoria: University of South Africa.

McCullagh, CB 2000. Bias in historical description, interpretation and explanation. History and Theory, 39(1):39-66.

Mader, JN 2012. WT Stead and the pro-Boer response to the South African War: Dissent through visual culture. Victorians Institute Journal Annex. Available at http:// www.nines.org/exhibits/_W_T_Stead_and_the_Pro-Boer_Re?page=-1. Accessed on 19 May 2015.

McInnes, M 1902a. Letter dated 25 August 1902. Cape Town.

McInnes, M 1902b. Letter dated 30 August 1902. Pretoria.

McInnes, M 1902c. Letter dated 5 September 1902. Irene.

McInnes, M 1902d. Letter dated 9 September 1902. Potchefstroom.

McInnes, M 1902e. Letter dated 22 September 1902. Potchefstroom.

McInnes, M 1902f. Letter dated 10 October 1902. Potchefstroom.

McInnes, M 1902g. Letter dated 28 October 1902. Potchefstroom.

McInnes, M 1902h. Letter dated 23 November 1902. Potchefstroom.

McInnes, M 1902i. Letter dated 14 December 1902. Potchefstroom.

McInnes, M 1903a. Letter dated 10 March 1903. Potchefstroom.

McInnes, M 1903b. Letter dated 2 April 1903. Potchefstroom.

McInnes, M 1903c. Letter dated 3 May 1903. Potchefstroom.

Miller, SM 2013. The British way of war: Cultural assumptions and practices in the South African War, 1899-1902. The Journal of Military History, 77:1329-1347.

Milner, A 1902. Chamberlain Papers JC13/1/216. Milner to Chamberlain 6 April 1902. Birmingham: Birmingham University Library. 
Otago Daily Times, 1902. 21 July.

Pakenham, T 1979. The Boer War. Johannesburg: Jonathan Ball Publishers.

Phillips, J 2012. South African War - New Zealand's contribution. Te Ara - the Encyclopedia of New Zealand. Available at http://www.TeAra.govt.nz/en/photograph/36198/ women-and-the-war-new-zealand-teachers. Accessed on 21 May 2015.

Phillips, RWD 2014. Arthur St Claire: The invisible patriot. Bloomington: iUniverse LLC.

Pretorius, F 2014. A history of South Africa: From the distant past to the present day. Pretoria: Protea Book House.

Pretorius, F 1998. The Anglo Boer War - 1899-1902. Cape Town: Struik.

Riedi, E 2002. Women, gender and the promotion of Empire: The Victoria League, 19011914. Historical Journal, 45(3):569-599.

Riedi, E 2005. Teaching Empire: British and dominions women teachers in the South African War concentration camps. English Historical Review, 120(489):1316-1347.

Sargant, EB 1901a. Public education. Sargant to Milner. 14 June 1901.

Sargant, EB 1901b. Sargant to the secretaries of the Transvaal and Orange River Colony administration 3 October 1901. National Archives: CO291/29 F39652.

Schoeman, C 2013. Angels of Mercy: Foreign women in the Anglo-Boer war. Parow: Zebra Press.

Scholtz, GD 2000. The Anglo-Boer War 1899-1902. Pretoria: Protea Book House.

Smith, IR \& Stucki, A 2011. The colonial development of concentration camps (1868-1902). The Journal of Imperial and Commonwealth History, 39(3):417-437.

Theal, GM 1882. Chronicles of Cape Commanders: An abstract of original manuscripts in the Archives of the Cape Colony, dating from 1651 to 1691, compared with Printed Accounts of the Settlement by various visitors during that time. Cape Town: Richards \& Sons, Government Printers.

Thompson JL 2007. Forgotten Patriot: A life of Alfred, Viscount Milner of St. James's and Cape Town, 1854-1925. New York: Fairleigh Dickinson University Press.

Transvaal and Orange River Colony 1904. Report of the Director of Education for the period November 1900 to February 1904. Appendix XXVIII. Petition to His Excellency the Lieutenant-Governor of the Orange River Colony, asking for the grant of more powers to School Committees \& ts., together with His 
Excellency’s reply. Johannesburg: Esson \& Perkins:115-122.

Transvaal Education Department, 1902. Transvaal administration reports for 1902. S.l.:s.n.

Tsoukas, H 1989. The validity of idiographic research explanations. Academy of Management Review, 14(4):551-561.

Van Heyningen, E 1999. The voices of women in the South African War. South African Historical Journal, 41:22-43.

Vergolina, JR 2012. Methods of barbarism or western tradition? Britain, South Africa, and the evolution of escalatory violence as policy. The Journal of Military History, 77:1303-1327.

Zietsman, P 2001. The concentration camp schools. In F Pretorius (ed.). Scorched Earth. Cape Town: Human \& Rousseau. 